not in use in the UK, but that is not my fault. Further, solar heat's marginal-cost advantage is not fragile but robust: even with collectors costing twice Dr Chapman's assumed $£ 50 / \mathrm{m}^{2}$, neighbourhood-scale seasonal-storage solar space heating in the UK should compete with any long-run marginal source and probably with OPEC oil too (see the Ann. Rev. En. article).

Fourth, my analysis assumed neither large wind machines nor growing special biomass crops (rather, it assumed the conversion of present farm and forestry residues requiring no additional land); and I did not ignore, but repeatedly emphasised, the economic argument for matching energy quality to end-use needs. One of the reasons for persistent official commitments to a hard energy path is the prevalence of asymmetric cost comparisons: governments compare the costs of various types of big power stations and synthetic-fuel plants with each other, then compare the costs of soft technologies not with their hard-technology competitors but with the historically cheap fossil fuels that all are meant to replace. This makes some soft technologies fail a test which hard ones would fail by a far wider margin. So long as such chicanery goes unremarked, economically and politically disastrous energy policies will continue to prevail over common sense.

Yours faithfully, AMORY B. Lovins

Friends of the Earth,

London, UK

\section{Gene inquiry is timely}

SIR,-Your editorial (8 December, page 461) criticised the decision of the House of Commons Select Committee on Science and Technology to set up a subcommittee on genetic engineering. It did so in remarkably complacent terms which seem to us to pass all too lightly over the problems which remain unexamined and unresolved in this area and to exaggerate the extent to which public debate has occurred. In our view it is not true to say there has been exhaustive scrutiny or debate in the UK of the issues involved. The "general feeling" of scientists involved in the field may be that the hazards have been overplayed, but this attitude ignores other issues which concern the public.

Many of the hazards involved in genetic engineering require much wider examination. The analysis so far has been far from comprehensive, and the actions taken incomplete. For example, recommendations made by the Ashby Committee three years ago, such as the institution of epidemiological surveys of workers in communities where these experiments are undertaken, have not yet been implemented. And the body established to regulate work in this field (the Genetic Manipulation Advisory Group) has few powers, relies on voluntary cooperation and is already experiencing problems in dealing with confidentiality of industrial information.

The examination of this area by the select committee could achieve much. It could help bring about a much wider appreciation of the far-reaching issues involved. It could also provide a valuable independent assessment of the policy-making procedures being created in this area which are currently screened from the public gaze by the protection of the Official Secrets Act. Now is the time for such an examination, before the problems of industrial exploitation are upon us. This is an urgent matter which requires as thorough an analysis as that at last being given to nuclear power.

We applaud the initiative taken by the select committee and feel sure that it will take the opportunity to take note of the wide range of views on this topic.

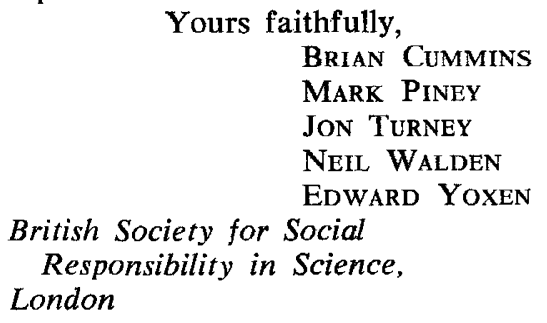

\section{What happened at Heimaey?}

SIR,--In his search for a deontological code for volcanology, Haroun Tazieff (8 September, page 96) has elected not to practise his own preaching and indeed based some of his own arguments "on deliberately false data". We are astounded by his inclusion of the waterchilling of the Heimaey lava in 1973 in his tabulation of erroneous volcanological diagnoses, and his account of countermeasures taken by Icelanders as defence against lava flows on Heimaey indicate either lack of familiarity with relevant literature or wrong interpretation of actual facts.

In an attempt to prevent westward advance of the Heimaey lava over the town and towards the harbour, earth dams were bulldozed in late January and early February 1973. Experiments with chilling of lava-fronts by waterpumping started on 6 February and while lava advance could not be prevented, local slowing-down and diversion was achieved. Thus chilling of lava in this way is believed to have saved electric power-line installations for a while and diverted lava from the harbour wall on
6 March. Subsequently, pumps with total capacity of 1,000 litres per sec were employed, feeding a network of $20 \mathrm{~cm}$ diameter flexible plastic tubing system from the harbour to the lava fronts which were threatening further destruction of the town. This large-scale operation resulted in doubling of height of some lava fronts (Th. Einarsson, The Heimaey Eruption, Heimskringla, Reykjavik (1974)) as production of clinker and blocky rubble was increased on the lava surface. This increasing clinker accumulation rate seems to have decelerated or halted advance of the lava in certain areas.

Our knowledge of the mechanics of lava movement is still rudimentary. Recent theories, such as that of Hulme (Geophys. Journ. Roy. Astr. Soc. (1974)), make it clear that the strength of the flow front and channel levees are of great importance in controlling lava shape. As lava levees or flow fronts are made stronger and thicker, lava builds up behind these natural barriers. Lava will clearly attempt to break out or advance at the weakest front. By preferentially strengthening a levee or flow front by such a technique as watercooling it seems probable that the lava will prefer to advance elsewhere. Levees or flow fronts are only minor parts of the total lava at any time, but increase in the strength of these areas may be highly effective in diverting lava. By choosing a strategic zone such as a levee, cooling need only be concentrated on a small part of the flow. Evidence from the Heimaey experiment suggests that the uncooled flow front ranged $10 \mathrm{~m}$ to $15 \mathrm{~m}$ in height, whereas the flow front treated by water pumping ranged from $20 \mathrm{~m}$ to $30 \mathrm{~m}$ and possibly as much as $40 \mathrm{~m}$.

Finally there is a requirement to substantially improve our understanding of lava flow mechanisms. This is an area of research that illustrates the importance of volcanology turning from a qualitative to a quantitative science. In this way some of the noticeable subjectivity in judging volcanic phenomena, which is amply illustrated in Dr Tazieff's note, can be replaced by informed opinion, based on detailed understanding of the physics and chemistry of volcanic processes.

The determination of the people in Heimaey in fighting the advancing lava was not daunted by defeatist utterances of some sceptics at the time of the eruption. We hope that readers of the otherwise useful note by Haroun Tazieff will likewise dismiss his pessimism about the usefulness of watercooling in diverting lava flows.

Yours faithfully,

HaRaldur Sigurdsson

STEPHEN SParks

University of Rhode Island,

Kingston, USA 